\title{
THE CATEGORY OF OPPOSITION IN LEXICAL AND SEMANTICAL ASPECTS (BASED ON RUSSIAN AND ENGLISH LITERATURE)
}

\author{
Farida Hamisovna Ismaeva \\ Kazan Federal University, Kremliovskaya str, 18, 420008, Kazan, Russian Federation \\ fismaeva@yandex.ru \\ Liya Akhatovna Kornilova \\ Kazan Federal University, Kremliovskaya str, 18, 420008, Kazan, Russian Federation. \\ tatpen@mail.ru
}

\begin{abstract}
Authors of the article represent a neat relevancy of the studied problem: the analysis of logical and philosophic category of opposition in the sight of its linguistic reflection. The aim of the article is to highlight the reflection of antinomy, which is considered as combination of mutually opposite statements about subjects and occurrence of reality, on antonymy in linguistics. Theoretical basis of the studied problem insures that the opposite nature of the universe is realized in various spheres of human activity with the help of contrast. Contrast principle underlies the organization of semiotic systems, such as philosophy and logic, architecture, painting, music and choreography, linguistics and stylistics. So long as language is a multilevel phenomenon, authors have developed the methodology the realization of linguistic contrast in different levels of Russian and English languages. As a result, of the given research we can define the following conclusions: the given analysis determines the contrast on all language levels, and demonstrates the multifaceted nature of the contrast, participated in a variety of structural and semantic types of opposition in English and Russian languages.
\end{abstract}

Keywords: contrast, opposition, opposite words, antonymy, antonym

\section{INTRODUCTION}

It is widely known that language, speech, vocabulary and, accordingly, the word is inextricably linked with thinking. Language functioning in a particular sound or semiotic form is the most important form of communication activity, which serves not only for the transmission of information from one person to another. It is also an essential tool for the designation of knowledge, ideas, feelings, and removed from the recesses of human memory and soul the information for himself, for his own development. It is the movement in the philosophical sense of the word.

Since the lexical system is based on universal development laws of the objective world, its contrast and opposition figures are certain to continue this world. Antinomy, as a combination of mutually contradictory statements about the objects and phenomena of reality, as well as implies the antonym with a word with the opposite meaning in linguistics. That is language with its antonym is the essence of reality, with all its contradictions and opposites.

The opposite nature of the universe is realized in various spheres of human activity with the help of contrast. Contrast principle underlies the organization of semiotic systems, such as philosophy and logic, architecture, painting, music and choreography, linguistics and stylistics. It is not surprising, since, according to E.V. Nazaikinskii, exactly in semiotic systems " duality is one of the important bases upon which the distinction between physical media value " [1].

Logical and philosophic aspect of opposition finds its linguistic expression in the phonetic, morphological, lexical, syntactic, stylistic, extra alphamerical types of contrast. 
The question of linguistic contrast was formulated back in the theses of Ferdinand de Saussure, "the whole linguistic mechanism revolves solely around identities and differences", "language is a system exclusively based on the opposition of its concrete units" [2]. It is obvious that these statements apply to all language systems, without exception, whether they are related or not, are made in one language family or different, ancient they are, dead or developing.

Universal human tendency to "polarize" the experience and value judgments - "think of opposites" is actualized in Russian and English languages .

For example, in the text of the poem B. Ahmadullina "Winter" [3] contrast is expressed by lexical opposition of antonyms light - shadow:

$$
\begin{aligned}
& \text { Свести себя на нет, } \\
& \text { чтоб вызвать за стеною }
\end{aligned}
$$$$
\text { не тень мою, а свет, }
$$

не заслонённый мною.

Word shadow, serving in the human mind as an expression as " a space to which light rays are not directly fall, as well as a dark reflection on anything on the subject, which is illuminated from the opposite side," [4], is a polar relationship with the word light, indicating " radiant energy perceived by the eye, making ambient light visible " [4].

The opposite meaning in English example is also made by the opposition of lexical antonyms to love - to hate (love - hate):

$$
\text { I know that I shall meet my fate }
$$

Somewhere among the clouds above;

Those that I fight, I do not hate,

Those that I guard, I do not love.

\section{(W. B. Yeats. An Irish Airman Foresees His Death.) [5]}

The semantics of this poetic expression is associated with a clear polarization of such universal concepts as hatred - "a strong sense of hatred and disgust " [6] and love - "a sense of self-sacrificing , heart affection " [7]

\section{MATERIALS AND METHODS}

The research of identities' and differences' problem in linguistics were first formulated by N.S. Trubetskoy as a theory of phonological oppositions. The concept of opposition in his works used to refer to the paradigmatic opposition [8].

Later in the works of some linguists, the terms "opposition" and "contrast" were used to describe two types of opposition - the paradigmatic and syntagmatic. For example, in the works of Martine "contrast" is defined as " the relationship between the speech circuit units, and the opposition - as the relationship between the units belonging to the same paradigm as opposed to the system" [9].

I.V. Arnold [10] in "Stylistics of Modern English Language" examines the semantic opposition as the ratio of the partial differences between partly similar linguistic units and identifies the following contrasting seed: extra linguistic - linguistic, mandatory - additional, updated - potential hidden - implicational, hyperemic hypoxemic, denotative - connotative, of usual - occasional.

In contrast to the semantic analysis of the links directly within the words proposed by Arnold, M.V. Nikitin considers the semantic connections between individual language units. According to his theory, opposites - 
are names with the opposite meanings. They are based on the opposite or incompatible characteristics, which are reflected in the meaning of words. Thus, the phenomenon and the problem of the opposition is transformed into a linguistic phenomenon and the linguistic problem of semantic opposites [11].

From the above it can be concluded that the terms opposition and contrast do not have a neat and clear understanding in linguistics, comparing with philosophical exact definition. In this area, a lot of confusion reigns, and one of the reasons, according to the scientist, is that the most experts in semantics paid little attention to different kinds of opposites.

\section{RESULTS}

Indeed, the task of studying the many varieties of opposites are implemented on various language levels, yet to be solved, and this article will help to solve nearer this problem.

Although there is no single term that defines the concept of opposites in linguistic, we can say that the basis of it is the theory of oppositions.

In our view, the contrast as a linguistic concept is a way of dividing the linguistic personality phenomena and processes of the universe into components for the purpose of analysis and synthesis for orientation in space. The process of human interaction with the surrounding reality implies nomination and description of not only the opposition in linguistics, but opposite concepts in the world of science, music, dance, architecture, literary works, visual arts.

Since the language - the phenomenon of multi-level, it is logical to consider the implementation of linguistic contrast at different language levels.

Researcher O. Martynova, studying how expressive contrast is contrasting in macro system of the whole text in the English-language story proves that the contrast is manifested on different levels of language. So, as an example of the expression of opposites on the phonetic level, said the author gives such opposition: " voiced - voiceless consonants $([\mathrm{b}]-[\mathrm{p}])$, occlusive - fricative $([\mathrm{t}]-[\mathrm{f}])$, the vowels of the front - back row ([a] - $[\mathrm{o}])$ " [12].

Later O.P. Martynova highlights the opposition as "the morphemic level, which includes a significant part of the elementary word: morpheme -ful - -less, on the level of lexemes - a pair of antonyms fortune misfortune; just - unjust; rise - fall ...» [12]. On "denomatic level (the level of the sentence)," according to O. Martynova, the contrast created "a variety of linguistic means: likening the metaphor, epithet" [13], it is implemented through a "positive opposition of prop sematic contrast level category is a negative proposal", "active and passive voices" on proposematic language level. At last, dictematic level, the contrast is through the opposition dictates.

Such analogies of actualization of the contrast category in English we can bring and use in the arsenal of Russian language system.

So, on the phonetic level of contrast, such as vowels and consonants: Rus. [и] - [г], Eng. [е] - [g]; front vowels and back vowels: Rus. [a] - [o], Eng. [a] - [o]; consonants are voiced and unvoiced: Rus. [д] - [т] Eng. [d] - [t], etc.

In the lexical- semantic level, the contrast can be expressed antonymous pairs: Rus. счастливый несчастный, начало - конеи; Engl. happy - unhappy, beginning - end etc.

On the denomatic level the opposite relationships arise using a variety of expressive means of the language, such as a figurative comparison: Rus. смерть была для него слаще жизни; Engl. Death was sweeter than life for him; metaphor: Rus. работа стала для него домом; Engl. Work became his home; epithet: Rus. его ужасающий вид не сочетался с чрезвычайно добрым сердием; Engl. His terrific appearance hasn't been combined with extremely kind heart.

On proposematic level the category opposition is realized through the opposition of positive and negative sentences, for example, in Russian language: «Существуют очевидности, которые ни за что на свете не докажешь, если человек умьиленно, а может, и вполне чистосердечно упрется. Разве докажешь 
материнскому сердиу, что ее ангелочек с некоторых пор стал горбатым уродом?» (А. Мушинский. Записки горбатого человека) [14]; in Engish: "White fingers and nimble tore at the string and paper. And then an ecstatic scream of joy. And then, alas! a quick feminine change to hysterical tears and wails, necessitating the immediate employment of all the comforting powers of the lord of the flat" (O. Henry. The Gift of the Magi) [15].

This level may also differ by the presence of the opposition expressed by means of active and passive constructions: Rus. мы долго строили дом, и, наконеи, он построился; если посмеешься над кем-то по утру, то будешь осмеян вечером; Engl.: we built the house for very long time and finally the house was built; if you laugh at someone in the morning, you will be laughed by someone in the evening.

The contrast on dictematic level is expressed by the opposition dictems, for example:

«В санатории гуляли бедняжки напропалую, вдруг да с кем зацепится, завяжется, и осуществится нормальная мечта нормальной женщины. Она, однако, не их поля ягода была. Но поэт по большому счету только тогда поэт, когда он ненормален. А я в качестве литератора был официально зарегистрирован творческим союзом. Не Байрон, конечно, но по местным меркам очень даже ничего. И необходимая ненормаленка имелась. Нет, больше, чем только необходимая, больше... Зато потом слишком нормален стал». (А. Мушинский. Записки горбатого человека) [16]

As an example from English language is the fragment of a story by O. Henry "The Purple Dress": "At five o'clock she went out upon the street wearing her purple dress. The rain had increased, and it beat down upon her in a steady, wind-blown pour. People were scurrying home and to cars with close-held umbrellas and tight buttoned raincoats. Many of them turned their heads to marvel at this beautiful serene, happyeyed girl in the purple dress walking through the storm as though she were strolling in a garden under summer skies" [17].

Thus, we can draw the following conclusions. The given analysis of the literature concerning the category of opposition, implementation antonymy in Russian and English, as well as determining the contrast on all language levels demonstrates the multifaceted nature of the contrast; it participated in a variety of structural and semantic types of opposition in English and Russian languages.

These examples clearly demonstrate the fact of actualization of the category of opposition in the creation of works of art imagery of these languages, as well as the contrast in dictematic forms of narration, description and reasoning. Comprehensive study of contrast at all language levels allows us to consider the contrast of the main principle of literary events display and therefore, the most important means of expression of the author concept of disclosure.

\section{DISCUSSION}

Classification of contrast and opposition was developed in the researches of S.K. Shaumyan and A.A. Reformatsky. [18,19].The category of contrast has been the subject of study in the fields of linguistics, morphology, grammar and semasiology. Morphological opposition gained a deep development in the works of Jacobson and Lotman, who noted that in the system of parts of speech often contrasted with verbs, pronouns and conjunctions. Analyzing the grammatical opposition, researchers agree that the basis of the grammatical category is the opposition of forms and meanings - the category number, type and time.

\section{ACKNOWLEDGEMENTS}

The work is performed according to the Russian Government Program of Competitive Growth of Kazan Federal University.

\section{REFERENCES}

[1] Neznaykinsky E.V. On psychology of musical perception. - M., Music, 1972. - P. 76.

[2] Saussure, F., de. Course in General Linguistics. - M., Logos, 1999. - P. 108-109.

[3] Ahmadullina B.A. Poems. - M., Eksm, 2007. - P. 184.

[4] Ozhegov S.I. Dictionary of Russian language. - M., 2008. - p. 565. 
[5] Yeats W. B. Collected Poems. - Cambridge University Press, 2008. - P. 402.

[6] Ozhegov S.I. Dictionary of Russian language. - M., 2008. - P. 335.

[7] Ozhegov S.I. Dictionary of Russian language. - M., 2008. - P. 277.

[8] Trubetskoy N.S. Fundamentals of phonology. - M.: Aspekt Press, 2000. - 352 p.

[9] Martine A. Fundamentals of general linguistics . - Moscow, LIBROKOM, 2009. - P. 48.

[10] Arnold I. Basic scientific research in linguistics: Textbook. - M., Graduate School, 1991. - P. 7.

[11] Nikitin M.V. Based on linguistic theory of meaning. - M.: Vyssh.shk., 2008. - 188 p.

[12] Martynova O.P. Contrast both semantic and functional basis of a literary text: the case of Englishlanguage text of the short story: dissertations. ... Cand. Philology. Sciences: 10.02.04. - M., 2006. - P. 20.

[13] Martynova O.P. Contrast both semantic and functional basis of a literary text: the case of Englishlanguage text of the short story: dissertations. ... Cand. Philology. Sciences: 10.02.04. - M., 2006. - P. 28.

[14] Mushinskii A.H. Notes humpbacked man: Roman. - Kazan "Tatar book publishing house », 2000. - P. 78.

[15] O’ Henry 25 Best Stories. - Moscow, Jupiter-Inter, 2004. - P. 57.

[16] Mushinskii A.H. Notes humpbacked man: Roman. - Kazan "Tatar book publishing house », 2000. - P. 123.

[17] O’ Henry 25 Best Stories. - Moscow, Jupiter-Inter, 2004. - 142 p.

[18] Shaumyan S.K. Problems of theoretical phonology. - M. , 1962. - 194 p.

[19] Reformatsky A.A. Introduction to Linguistics, ed. 4. - M. Education, 1967. - P. 95-98. 